\title{
Microhabitat preferences of benthic foraminifera-a static concept or a dynamic adaptation to optimize food acquisition?
}

\author{
P. Linke ${ }^{\mathrm{a}}$ and G.F. Lutze ${ }^{\mathrm{b}}$ \\ ${ }^{a}$ Sonderforschungsbereich (SFB) 313, Olshausenstraße 40-60, Kiel University, 2300 Kiel, Germany \\ ${ }^{b}$ Geologisch-Paläontologisches Institut, Olshausenstraße 40-60, Kiel University, 2300 Kiel, Germany
}

(Received February 20, 1992; revision accepted August 15, 1992)

\begin{abstract}
Linke, P. and Lutze, G.F., 1993. Microhabitat preferences of benthic foraminifera-a static concept or a dynamic adaptation to optimize food acquisition? In: M.R. Langer (Editor), Foraminiferal Microhabitats. Mar. Micropaleontol., 20: 215-234.

In situ observations of microhabitat preferences of living benthic foraminifera are presented from sediments of the Norwegian-Greenland Sea, the upwelling area off northwestern Africa and the shallow-water Kiel Bight (Baltic Sea). Certain foraminiferal species (e.g. Cibicidoides wuellerstorfi and Rupertina stabilis) can be regarded as strictly epibenthic species, colonizing elevated habitats that are strongly affected by bottom water hydrodynamics. Large epibenthic foraminifera (e.g. Rhabdammina abyssorum and Hyperammina crassatina) colonize the sediment surface in areas where strong bottom currents occur and might have by virtue of their own size an impact on the small-scale circulation patterns of the bottom water. Motile species changing from epifaunal to infaunal habitats (e.g. Pyrgo rotalaria, Melonis barleeanum, Elphidium excavatum clavatum, Elphidium incertum, Ammotium cassis and Sphaeroidina bulloides) are regarded here as highly adaptable to changes in food availability and/or changing environmental conditions. This flexible behaviour is regarded as a dynamic adaptation to optimize food acquisition, rather than a static concept leading to habitat classification of these ubiquitous rhizopods.
\end{abstract}

\section{Introduction}

Benthic foraminifera have been reported from virtually all marine environments indicating a broad ecological adaptability. In oxygenated deep-sea sediments, foraminifera occupy epifaunal and shallow (0-2 cm) or deep $(>2 \mathrm{~cm}$ ) infaunal microhabitats (Corliss, 1985; Gooday, 1986; Altenbach and Sarnthein, 1989; Mackensen and Douglas, 1989; Thies, 1990). Some taxa which live infaunally in well-oxygenated sediments also occur near the sediment surface in dysaerobic environ-

Correspondence to: P. Linke, Kiel University, Sonderforschungsbereich (SFB) 313, Olshausenstraße 40-60, 2300 Kiel, Germany. ments suggesting that an ability to tolerate low oxygen concentrations allows these species to survive within the sediment (Mackensen and Douglas, 1989). Some epifaunal species live attached to firm substrates which elevate them above the sediment surface. At bathyal depths stones and biogenic structures offer suitable and readily available attachment surfaces (Lutze and Altenbach, 1988; Lutze and Thiel, 1989; Mackensen and Douglas, 1989; Gooday et al., 1992b). In the Norwegian-Greenland Sea the miliolid Miliolinella subrotunda achieves elevation by perching on top of a selfconstructed agglutinated tube that may be up to $6 \mathrm{~mm}$ long (Altenbach et al., 1992, this volume). Encrusting foraminifera also occur on surfaces close to hydrothermal vents (Van 
Dover et al., 1988; Lee, 1990) and in oligotrophic central oceanic regions where manganese nodules are widely available as a substrate (Mullineaux, 1987, 1988a,b). Some large agglutinated foraminifera stand upright in the sediment so that the distal parts from which the pseudopodia arise project well above the sediment-water interface (Tendal and Thomsen, 1988; Cedhagen, 1988; Gooday, 1990 ), thereby gaining access to a richer and fresher food supply than is available at the sediment surface (DeLaca et al., 1980; Altenbach et al., 1988; Mullineaux, 1989).

The relationship between the vertical distribution of benthic foraminifera and the amount of organic carbon in the sediment has been the subject of a number of reports (e.g., Miller and Lohmann, 1982; Corliss, 1985; Jorissen, 1987; Van der Zwaan and Jorissen, 1991; Jorissen et al., 1992). Recently, it has been suggested that not only the faunal composition, but also the faunal morphology changes in relation to the amount of organic matter in the sediment and that these variations are related to the life position of the foraminifera (Bernhard, 1986; Corliss, 1985; Corliss and Chen, 1988; Jorissen, 1988). Implicit in the discussion so far is the assumption that many taxa are either epifaunal or infaunal (e.g. Corliss and Fois, 1990) and that microhabitat preferences of benthic foraminifera can be classified within this static concept (e.g., Corliss and Emerson, 1990; McCorkle et al., 1990; Corliss, 1991).

In the present study we integrate numerous single observations of our working group (consisting of micropaleontologists and biologists of the SFB 313 at the University Kiel) to elucidate microhabitats and behavioural strat- egies of benthic foraminifera. These investigations arose from earlier studies on foraminiferal assemblages (Lutze, 1965; Wefer, $1976 a, b)$ and were guided by the growing realization that adaptation to nutritional conditions rather than to water-mass properties or other physical parameters alone control foraminiferal distribution (Altenbach, 1985; Lutze et al., 1986; Altenbach and Sarnthein, 1989; Lutze and Thiel, 1989; Linke, 1989; Altenbach, 1992; Gooday et al., 1992a; Sjoerdsma and Van der Zwaan, 1992).

\section{Material and methods}

During the Meteor-cruises (NorwegianGreenland Sea, northwestern Africa) a specially equiped "biocontainer" situated on deck of the research vessel, was used for live observations (Plate I, A). Immediately upon recovery of large box corers $(50 \times 50 \mathrm{~cm}$ surface area) the sediment blocks with overlying water were transferred onto a hydraulic lift in the isolated and air-conditioned container. The sediment surfaces were examined using a binocular microscope (Wild, M650). This microscope could be placed directly above the sample cores by means of a flexible arm, eliminating the need to handle the sample prior to microscopy. Foraminifera visible at the sediment surface were photographed and picked out with forceps and pasteur pipettes for further investigations.

Sediment cores were taken with a multiple corer (modified from Barnett et al., 1984) using plexiglass tubes with a $10 \mathrm{~cm}$ inner diameter, or subcores were taken from the large box corer. The top and the bottom of each sedi-

Plate I

A. View into the "biocontainer", specially equiped for live observations on deck of the R.V. Meteor. B. A dense patch of suspension-feeding Rupertina stabilis colonizing a small rock (scale bar $=1 \mathrm{~mm}$ ). The pseudopial net is spread between errected sponge spicules and is covered with resuspended particles. C. Densely colonizing Rupertina stabilis construct common pseudopodial nets (arrow) in several hours (scale bar $=1 \mathrm{~mm}$ ). D. View into a crustacean burrow with ( $a$ ) Rhabdammina abyssorum and $(b)$ Rupertina stabilis at its wall, extending their pseudopodia into the respiratory current of the megafaunal inhabitant (scale bar $=5 \mathrm{~mm}$ ). E. High densities of Cibicidoides wuellerstorfi on the stem of a crinoid (scale bar $=800 \mu \mathrm{m}$ ). 

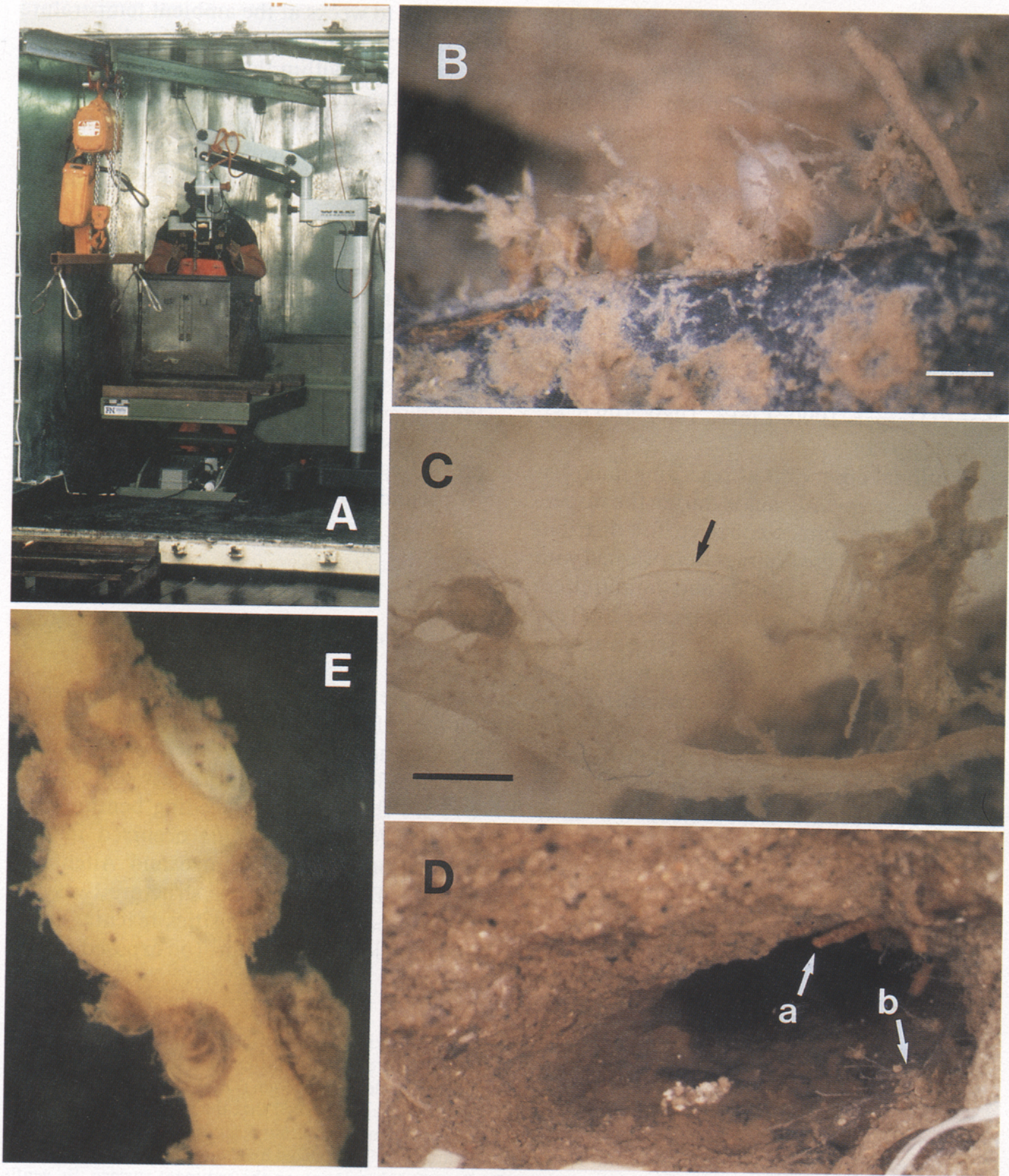
ment core was stoppered with 'Delrin' and the cores were kept in a temperature-controlled refrigerator close to in situ temperature $\left(-0.7^{\circ} \mathrm{C}\right)$ or in the cooling room of the ship. The upper centimeter of each sediment core was removed and gently washed with precooled seawater on a plastic sieve with a mesh size of $250 \mu \mathrm{m}$. The remains in the sieve were transferred into glass petri dishes and living foraminifera were picked out with forceps under a dissecting microscope (Wild, M8) for further analyses (Transmission/Scanning Electron Microscopy, measurements of biomass and metabolic activity) reported elsewhere (Heeger, 1990; Linke, 1989, 1992; Altenbach, 1992).

Additional observations regarding microhabitats were frequently made during the inspection of dried samples collected for distributional studies. These samples were washed with great care. Larger particles and foraminifera were picked during the initial phase $(2000 \mu \mathrm{m}$ mesh-sieve). Attached and semi-attached specimens can be observed very often clinging to tubes of large arenaceous foraminifera having tests which project above the sediment surface. If the attached specimen and the foraminifer serving as a substratum are well stained, then we consider this as an indication of an elevated microhabitat.

In the Kiel Bight observations were made on foraminifera in subcores of a Reineck box corer $(20 \times 30 \mathrm{~cm}$ surface area $)$. Intact cores were transferred to a cooling room, and kept for sev- eral days to weeks at the ambient temperature $\left(5^{\circ} \mathrm{C}\right)$. Individuals visible at the sediment surface or living within the sediment and visible through the transparent wall of the plexiglas tubes, were observed over longer periods and finally picked out with forceps and pasteur pipettes. Otherwise, a spoonful of sediment was transferred into a petri dish with ambient seawater and carefully examined for living foraminifera. The foraminifera were gently cleaned of adhering detritus. Samples were kept at in situ temperature by means of a cooling stage built on the microscope table (Linke, 1989). Live individuals were identified according to the following criteria: the presence of protoplasm visible through the test, plasma threads and a plug of accumulated detrital matter built by pseudopodial activity around the apertural region.

\section{Results}

\section{Observations of elevated microhabitats}

On the Norwegian continental margin, a biotope of suspension-feeding benthic animals extends northwards from the Vøring Plateau for 200-300 km. At depths between 600 and $800 \mathrm{~m}$, the suspension-feeding benthic foraminifer Rupertina stabilis occurred in high population densities (Lutze and Altenbach, 1988). The population structure was extremely patchy with densities reaching up to 100 individuals per $10 \mathrm{~cm}^{2}$ (on exposed rocks).

\footnotetext{
Plate II

A. Scanning electron micrograph of two Cibicidoides wuellerstorfi colonizing the posterior extremity of the pantopod Achelia echinata. Apertures of the epizoic foraminifers are oriented towards the tip of the extremities (i.e. the former sediment surface and the main flow direction of resuspended particles; scale bar $=400 \mu \mathrm{m}$ ). B. A closer view of the pantopod hairs (indicated by an arrow pointing to the white box) is shown and revealed that the side of the hairs facing towards the sediment surface are covered with particles (arrow: a coccolith of Coccolithus pelagicus) (scale bar $=10 \mu \mathrm{m}$ ). C. Ventral side of the pantopod Achelia echinata. The extremities are densely colonized by Cibicidoides wuellerstorfi that are covered by resuspended material (scale bar $=3 \mathrm{~mm}$ ). D. Pyrgo rotalaria lying on the sediment surface. By gently pumping seawater with a pasteur pipette, the flocculent sediment was swept away and a plug of detrital material accumulated by pseudopodial activity became visible (scale bar $=500 \mu \mathrm{m}$ ). E. Pyrgo rotalaria colonizing a stone. The test of the foraminifer is covered with resuspended material that is gathered at the apertural region by pseudopodial activity ( scale bar $=500 \mu \mathrm{m}$ ). F. Cribrostomoides subglobosum extending long whip-like plasma threads for scavenging the sediment surface (scale bar $=600 \mu \mathrm{m}$ ).
} 

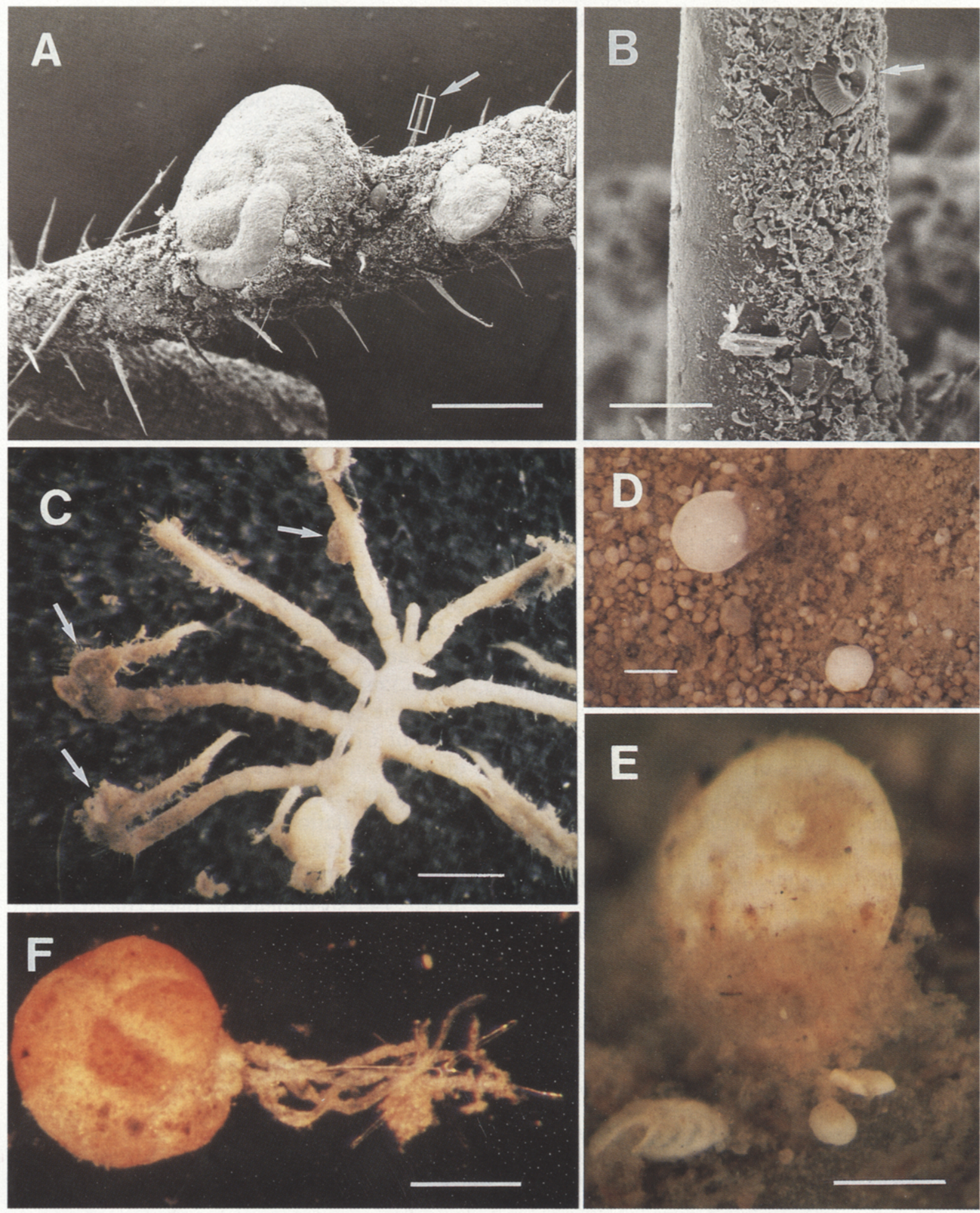
Attached to hard substrates and obviously prefering elevated positions, this species is exposed to bottom currents (Plate I, B). Around its apertural region Rupertina stabilis erects sponge spicules that allow it to spread its fragile protoplasm into the water where it functions as a pseudopodial net, obviously enhancing food acquisition. The spicules were always arranged upright, even by those individuals growing in a more horizontal direction. Individuals kept in laboratory aquariums at in situ temperature were active and altered their pseudopodial net construction over the course of several hours in response to changing currents from the inflow of filtered seawater. Densely colonized individuals, with their spicules almost touching, constructed common pseudopodial nets which partly overlapped (Plate I, C).

In the basins and on the lower continental slope ( $>2000 \mathrm{~m}$ ) of the Norwegian-Greenland Sea, the foraminiferal fauna is characterized by an extremely low species diversity (29 species per 100 counted foraminifera in the size fraction $>250 \mu \mathrm{m})$. Cibicidoides wuellerstorfi, Cribrostomoides subglobosum, Pyrgo rotalaria and Crithionina hispida represent between 80 and $100 \%$ of the total fauna (Lutze and Salomon, 1987; Thies, 1991 ). Other species present are Cibicidoides wuellerstorfi, Crithionina hispida and the less abundant Miliolinella subrotunda, all showing a preference for elevated microhabitats.

Cibicidoides wuellerstorfi is an epibenthic foraminifer living in elevated positions above the sediment surface (Lutze and Thiel, 1989). In the Norwegian Sea we found Cibicidoides wuellerstorfi attached to stones, shells, sponges, polychaete and pogonophore tubes, crinoid and hydrozoan stalks and even on vagrant macrobenthos, at much higher population densities than hitherto reported from sediment samples. On stones, protruding approximately 3 to 5 $\mathrm{mm}$ above the sediment surface, patches with densities of $100-280$ specimens per $10 \mathrm{~cm}^{2}$ were reported (Lutze and Thiel, 1989). These patches were situated at the most elevated edge of the stones, presumably facing the bottom water flow. This position could possibly reflect the settlement of propogules (Mullineaux, 1988b) of Cibicidoides wuellerstorfi on exposed hard-substrates.

Between 4 to 8 specimens colonized biogenic structures such as the tubes of the filterfeeding polychaete Potamethus mahngreni. The very flexible tube of this sabellid consisted of a membranous carpet with a silty cover. The tubes were $10 \mathrm{~cm}$ long (of which the lower 1$2 \mathrm{~cm}$ anchored the tube in the sediment) and $0.9-1.5 \mathrm{~mm}$ in diameter.

On the crinoid Bathycrinus, dense populations of Cibicidoides wuellerstorfi were found up to $14 \mathrm{~cm}$ above the sediment surface (8-22 specimens per crinoid, see Plate I, E). An even higher population density was found on two crinoids recovered from one box corer at station M109 $\left(70.00^{\circ} \mathrm{N}, 3.00^{\circ} \mathrm{W}, 3222 \mathrm{~m}\right.$ water depth, 144 specimens on one crinoid). Both crinoids were colonized by hydrozoans, which also provided a substrate for the foraminifera.

Plate III

A. Sediments cores (Kiel Bight, $28 \mathrm{~m}$ water depth) kept for several days without the addition of oxygen, became covered with mats of the sulfur-oxydizing bacteria Beggiatoa. Tubes of the polychaete Polydora ciliata are protuding through the stagnant viscous sublayer (scale bar $=1 \mathrm{~mm}$ ). B. A closer view of the polychaete tube shows the top colonized by Elphidium sp. The ciliated palps of the tube inhabitant Polydora ciliata are visible (scale bar $=600 \mu \mathrm{m}$ ). C. A dense cluster of Elphidium sp. on top of a polychaete tube. Note the darkish-green protoplasm (scale bar $=600 \mu \mathrm{m}$ ). D. Dense patches of Elphidium sp. during oxic periods of the bottom water. The sediment surface is composed of faecal pellets only. Note the orange protoplasm of one specimen (arrow) in contrast to the dark color of other foraminifera (scale bar $=600 \mu \mathrm{m}$ ). E. Burrow of Elphidium excavatum clavatum in a sediment depth of $4 \mathrm{~cm}$. The apertural face is oriented towards the burrow (scale bar $=600 \mu \mathrm{m}$ ). F. Elphidium incertum gathering mineral and detritic material by pseudopodial activity to build an agglutinated cyst ( scale bar $=200 \mu \mathrm{m}$ ). 

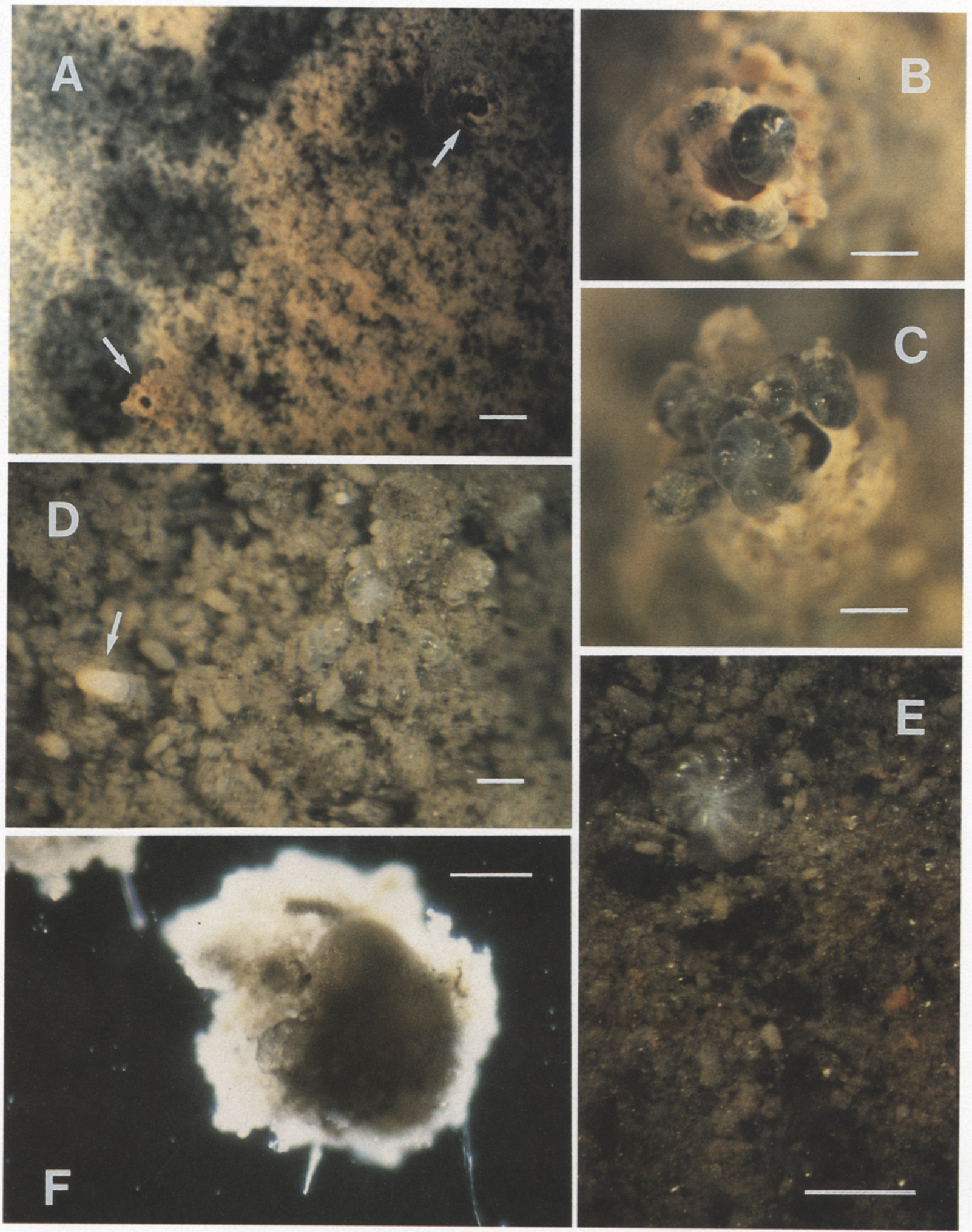

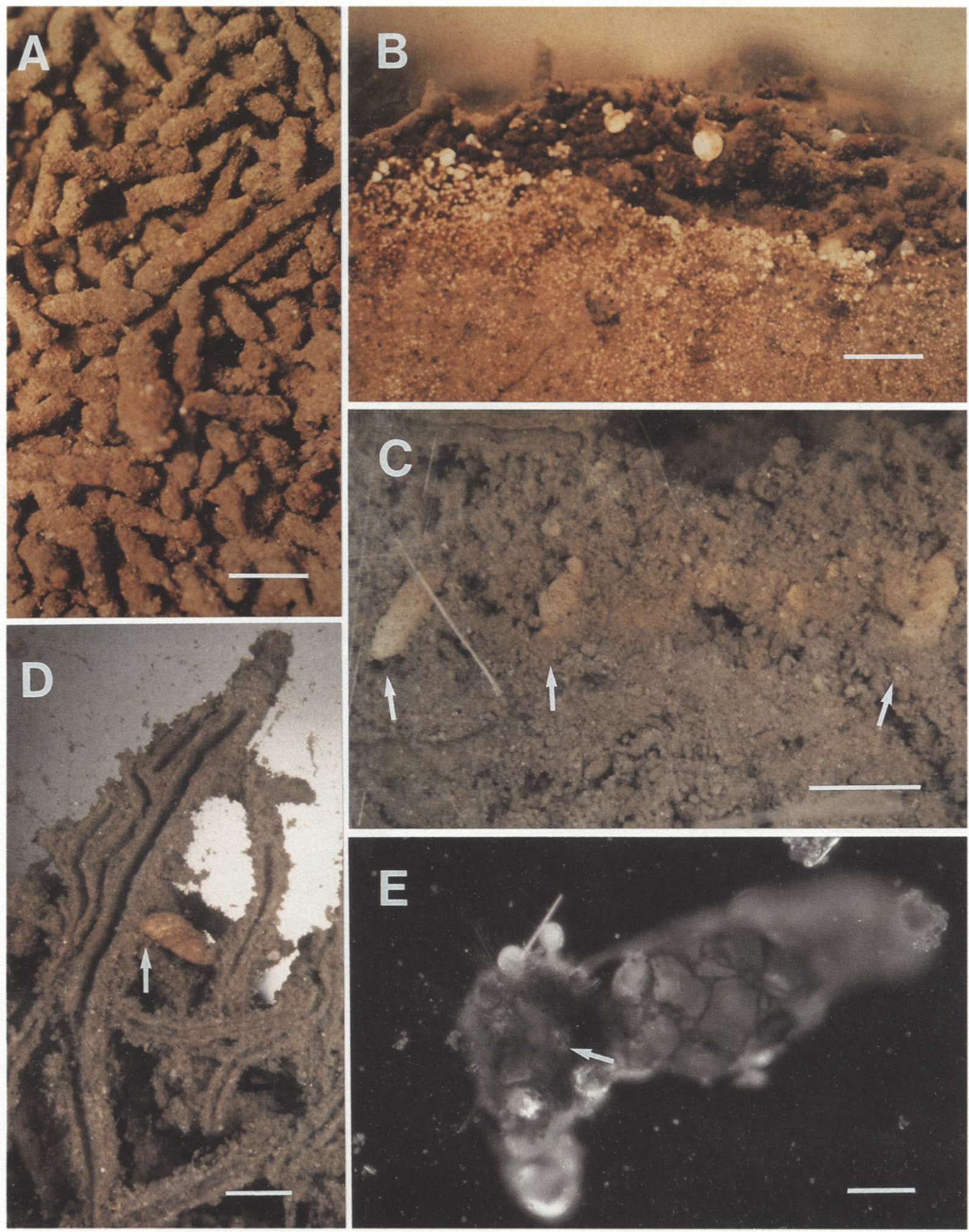
The pantopod Achelia echinata was colonized by Cibicidoides wuellerstorfi in densities of 9-23 specimens per pantopod (Plate II, C). The posterior extremities of the pantopod were preferably colonized. Another pantopod species, Nymphon rubrum, with fewer spines and hairs was not colonized. The aperture of the epizoic foraminifera were oriented towards the sediment surface (Plate II, A). A closer view revealed that the side of Achelia echinata hairs facing towards the sediment surface were covered with particles (Plate II, B). Thus, the foraminifera seemed to be oriented in the direction of the main flow of resuspended particles.

An extreme form of epizoic colonization was the attachment of Cibicidoides wuellerstorf $i$ on the lateral setae and the dorsal elythrae of an errant polychaete (Aphroditidae). Heeger (1990) showed that more than $50 \%$ of the spines were colonized by one or more foraminifera. The polychaete is an omnivorous predator and provides the epizoic foraminifera with a source of resuspended particles by rummaging for food in the sediment surface layer.

\section{Observations of microhabitats on the sediment surface}

Another benthic foraminifer in the biotope of suspension feeders on the Norwegian continental margin, Rhabdammina abyssorum, lacks the morphological adaptations of Rupertina stabilis. Rhabdammina abyssorum was generally found lying on the sediment surface, accumulating detrital material by pseudopodial activity. In one case, Rhabdammina abys- sorum and Rupertina stabilis were observed together on the inner wall of a crustacean burrow, extending their pseudopodia into the respiratory current of the megafaunal inhabitant (Plate I, D).

An extremely dense occurrence of large agglutinated foraminifera covering the sediment surface was observed on the East Greenland shelf where current velocities of $30-40 \mathrm{~cm} \mathrm{~s}^{-1}$ occur (Gammelsröd and Rudels, 1983; Bourke et al., 1987). Sediments are characterized by abundant Hyperammina crassatina, present in the uppermost sediment layer (Meyer-Reil and Köster, 1991; Köster et al., 1991). Below the uppermost sediment layer, living agglutinated foraminifera were not present. Most of the foraminiferans were inactive or dead with population densities of 1-6 living individuals per 10 $\mathrm{cm}^{2}$ (A. Thies, pers. commun., 1991). These assemblages resemble more closely a cemetery (thanatocoenosis) than a densely populated biotope (Plate IV, A and B). However, living specimens of Hyperammina crassatina accumulate organic particles in their pseudopodial nets, which extent above the sediment surface. This was demonstrated by measurements of chlorophyll $a$ (a tracer of algal cells) in individual specimens (A. Thies, pers. commun., 1991).

\section{Observations on versatile microhabitat selection}

\section{Norwegian Sea}

On the Vøring Plateau (Norwegian Sea) the soft sediment type and gradual slope reflect a calm sedimentation environment that is less

Plate IV

A. View of the sediment surface (East Greenland shelf) covered exclusively by tests of Hyperammina crassatina (scale $\mathrm{bar}=10 \mathrm{~mm}$ ). B. Side view of the sediment core. The uppermost centimeter is covered by Hyperammina crassatina (scale bar $=8 \mathrm{~mm}$ ). C. Side view of a sediment core (Kiel Bight, $17 \mathrm{~m}$ water depth). Apertural faces of Ammotium cassis (arrows) oriented towards the Redox Potential Discontinuity Layer (RPDL), that is indicated by a change in color (brown to grey). Feeding foraminifers apparently built a cavity in front of their aperture (scale bar $=3 \mathrm{~mm}$ ). D. Side view of a sediment core (Kiel Bight, $17 \mathrm{~m}$ water depth) with Ammotium cassis (arrow) ascending the tube of polychaete Polydora ciliata (scale bar $=2 \mathrm{~mm}$ ). E. View into the apertural region of Ammotium cassis by use of an inverted microscope. The foraminifer lifts its test by means of pseudopodia into an upright position. The accumulated detritus in front of the aperture is funnel shaped, the inside covered by pseudopodia (scale bar $=50 \mu \mathrm{m}$ ). 
influenced by gravitational down-slope transport processes. Pyrgo rotalaria and Cribrostomoides subglobosum were found living on the sediment surface and within the uppermost sediment layer $(0-3 \mathrm{~cm})$. Those scavenging at the sediment surface develop long whip-like plasma threads to draw even large particles towards their aperture (Plate II, F). By gently pumping seawater (with a pasteur pipette) at the apertual region of Cribrostomoides subglobosum, flocculent sediment was swept away and the total length of the pseudopodial net, extending several millimeters on the sediment surface, became visible. Those individuals found in surface sediments had a 'plug' of accumulated detrital matter built by pseudopodial activity around the apertural region (Plate II, D). The miliolid Pyrgo rotalaria was observed (through the transparent wall of plexiglass tubes) migrating through the sediment to a depth of $2 \mathrm{~cm}$ with the aperture in front, leaving burrows slightly smaller than the test diameter. It was also found colonizing small stones on the sediment surface. The test stood in an upright position on the substrate and resuspended particles were gathered by the broadly extended pseudopodial net (Plate II, E).

On the lower Norwegian continental slope (960 $\mathrm{m}$ water depth ), Melonis barleeanum was found in maximum abundance between 3 and $4 \mathrm{~cm}$ sediment depth (Lutze, 1987). This corroborates other studies where Melonis barleeanum was similarly found in sediment depths of several centimeters (Corliss, 1985; Gooday, 1986; Corliss and Emerson, 1990). However, in sediment cores from the same station taken at different times of the year (February and late October 1987), Melonis barleeanum was observed in high densities at the sediment surface.

\section{Response to environmental fluctuations}

During oxic bottom water periods in the Kiel Bight (Baltic Sea) the sediment surface seems to be composed only of faecal pellets (pro- duced by macrofaunal organisms like Polydora ciliata, Capitella capitata and Heteromastus filiformis). The usually fluffy sediment surface becomes more consolidated and the pellets are consequently densely populated by Elphidium excavatum clavatum (Plate III, D). A steel plate, its underside covered with a $2 \mathrm{~mm}$ thick layer of adhesive Vaseline was used by SCUBA divers to sample the fluffy sediment surface layer (Wefer, 1976a). Samples obtained in this fashion revealed mean population densities of 200 Elphidium excavatum clavatum per $10 \mathrm{~cm}^{2}$ in the uppermost millimeters of sediment.

During oxic periods, dense patches of polychaete tubes were observed on the surfaces of sediment cores recovered from a water depth of $28 \mathrm{~m}$. These tubes were built and inhabited by Polydora ciliata (Fam. Spionidae). The tubes are U-shaped with two chimneys oriented lopsided or vertically and anchored 2-5 $\mathrm{cm}$ deep in the sediment and are irrigated by the activity of dorsal and gill ciliae of the polychaete (Hempel, 1957; Daro and Polk, 1973). The animals feed by extruding their ciliated palps on the sediment surface or into the water column and gather detrital particles at their oral region. Already after recovery of sediment cores the polychaete tubes were colonized above the sediment surface by Elphidium excavatum clavatum. The observed specimens were covered with sediment particles that were resuspended during recovery and transport of the sediment cores, indicating that Elphidium excavatum clavatum is capable of gathering suspended particles.

In the present study, Elphidium incertum and Elphidium excavatum clavatum were observed through the plexiglass walls of the cores to sediment depths of up to $8 \mathrm{~cm}$. Elphidium excavatum clavatum was found at a sediment depth of $4 \mathrm{~cm}$ building a cavity in front of its aperture by pseudopodial activity. The aperture was oriented towards the already finished burrow (Plate III, E). The sediment was covered by a dense lawn of polychaete tubes. It is difficult to determine whether the foraminifera were 
themselves burrowing to that depth, or whether they were transported down from the sediment surface by bioturbative activity of the macroand meiofauna. Nevertheless, the occurrence of Elphidium excavatum clavatum in the sediment seemed to be closely related to the degree of colonization of Polydora ciliata. In cores densely populated by Polydora ciliata ( $>8$ tubes $\mathrm{cm}^{-2}$ ), the abundance of Elphidium excavatum clavatum in the $0-1 \mathrm{~cm}$ sediment layer was about 15 , in the $1-2 \mathrm{~cm}$ layer 19.5 , in the $2-3 \mathrm{~cm}$ layer even 47.5 , and in the $3-4 \mathrm{~cm}$ layer still 11 times higher, compared to sediments without Polydora ciliata (Schmager, 1988).

After several days at ambient temperature with no additional oxygen supply, the sediment surface was colonized by mats of sulfuroxydizing bacteria (Beggiatoa sp.), indicating that even the thin oxidized layer on the sediment surface was becoming anoxic (Plate III, A). The bacterial mats covered the sediments like a carpet, consolidating the fluffy anoxic black surface. During this period, the number of foraminifera visible at the sediment surface increased dramatically, invading the polychaete tubes and the plexiglass walls of the cores (Plate III, B and C). Some individuals were even seen free-floating at the water surface, extending their pseudopodia at the water-air interface (see also Sheehan and Banner, 1972). In his studies in the southern North Sea, Richter (1965) suggested this behaviour was a distribution mechanism of Elphidium. Foraminifera, especially those living at the sediment surface, might be suspended by the approaching high tide and transported to the high tide sea level.

Specimens observed on the polychaete tubes, escaping anoxic conditions of the sediment, had a darkish-green protoplasm (Plate III, B and C). Elphidium excavatum clavatum can store large numbers of isolated chloroplasts in their protoplasm (Heeger, 1990). These chloroplasts may be responsible for the greenish protoplasm of the foraminifera. The capture and ingestion of harpacticoid copepods by $E l$ - phidium may lead to a different protoplasmic color (Linke, 1986). Our live observations in the Baltic and the North Sea revealed that the protoplasm color of Elphidium sp. is usually brownish-orange (Plate III, D). Thus, the adaptation of Elphidium to new microhabitats also results in a shifting nutritional behaviour that is characterized by changes in the protoplasm color.

In sediment cores from 17 and $19 \mathrm{~m}$ water depth, Ammotium cassis was observed either on the sediment surface or infaunally (3-4 $\mathrm{cm}$ ). On the sediment surface specimens laid horizontally on the sediment surface or were attached to tubes of Polydora ciliata (Plate IV, D). This species was observed in very high densities $(35,190$ individuals per square meter) either under, or in between the polychaete tubes (Schmager, 1988). In sediment cores kept in the laboratory at ambient temperature without the addition of oxygen, Ammotium cassis ascended within $24 \mathrm{~h}$ from a depth of 2$3 \mathrm{~cm}$ to the sediment surface and 10 individuals were observed ascending polychaete tubes. Using an inverted microscope, it was possible to observe Ammotium cassis lifting its test in an upright position by means of the pseudopodia, enabling an observer to look into the aperture (Plate IV, E). Accumulated detritus in front of the aperture was funnel-shaped, the inside of the funnel covered by pseudopodia that were dragging smaller particles through the aperture and into the test. Viewing deeper sediment layers (through the wall of the plexiglass cores) revealed that Ammotium cassis was concentrated at the Redox Potential Discontinuity Layer (RPDL), indicated by changes in sediment color (brown to grey, see Plate IV, C). These foraminifera built a cavity in front of their aperture by pseudopodial activity and were obviously feeding.

\section{Encystment}

Elphidium incertum exhibited another strategy of adaptation. The favored habitat of $\mathrm{El}$ phidium incertum are the uppermost sediment 

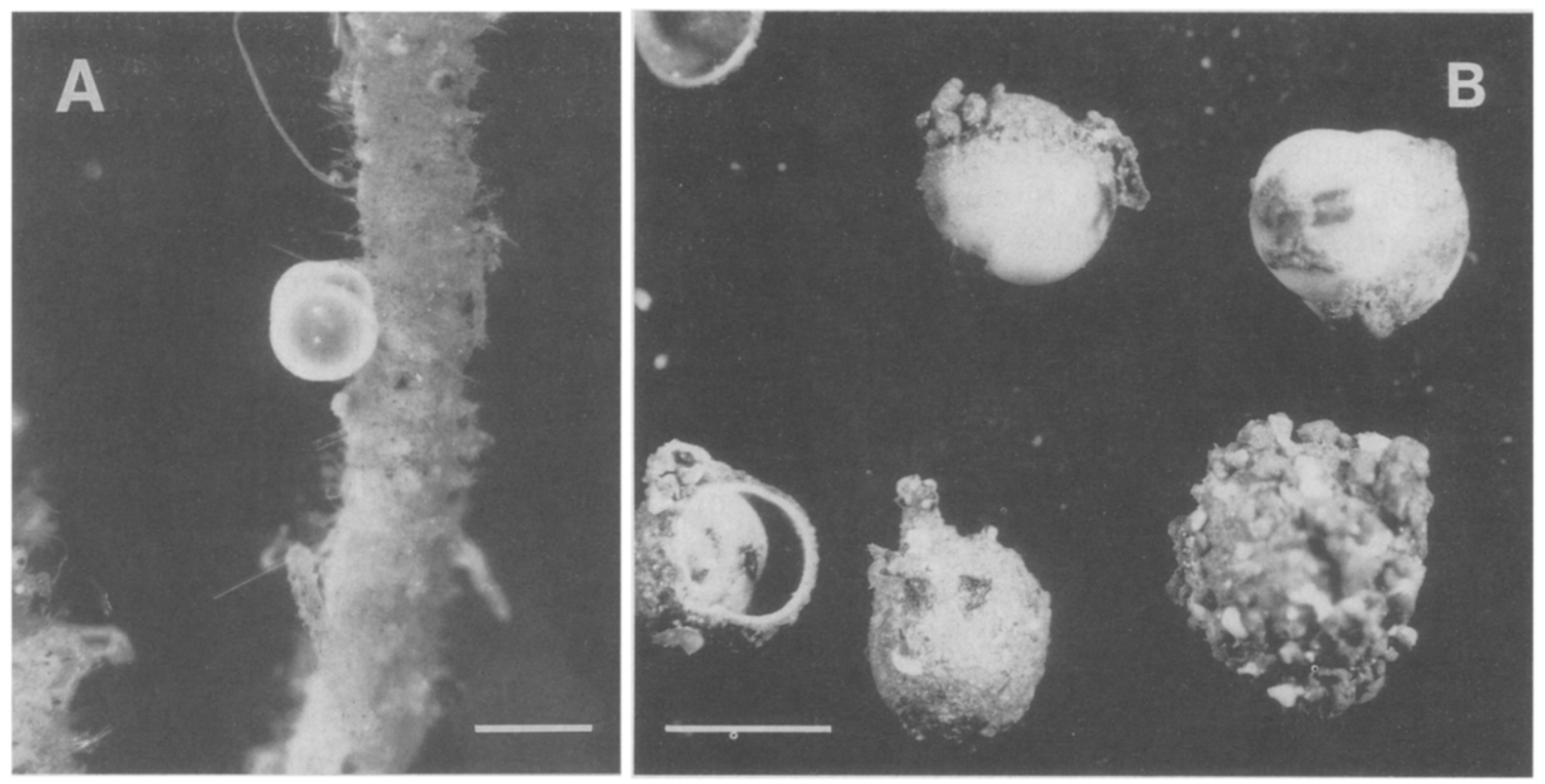

Fig. 1. (A) Sphaeroidina bulloides attached to a tube of Sacchoriza ramosa extending several millimeters above the sediment surface (from station 16764 , off Guinea, $885 \mathrm{~m}$ water depth). Both tests were filled with stained protoplasm (scale bar $=400 \mu \mathrm{m}$ ). (B) Sphaeroidina bulloides from station 16802 , off Ivory Coast (691 m water depth). All specimens were filled with stained protoplasm and firmly coated with mud cysts (scale bar $=700 \mu \mathrm{m}$ ).

layers and not the sediment surface (Wefer, $1976 \mathrm{~b})$. In greater sediment depths $(3-6 \mathrm{~cm})$ this species was found in agglutinated cysts. Elphidium incertum cultivated in petri dishes gathered mineral grains by pseudopodial activity (Plate III, F), moved the material into position and cemented it into a rigid detritic cyst wall. Cysts containing living specimens were even found in anoxic sediment layers but did not show any sign of carbonate solution. Using light microscopy the space between cyst and test became visible and small nematodes, ciliates, flagellates and numerous other protozoa were observed in this microhabitat created by the foraminifera. The prominent colonists on the outer surface of the cyst were bacteria, that were also present in between cyst and test surface. Test surfaces of nonencysted foraminifera were colonized by comparably few bacteria.

The upper bathyal species Sphaeroidina bul- loides is widely distributed on the continental slope of the Northeastern Atlantic Ocean. In routine samples of surface sediment, usually only small numbers of living (stained) specimens were observed in proportions to the assemblage of empty tests. Occasionally, stained specimens were observed that were firmly attached to the stained tubes of Saccorhiza ramosa (Fig. 1A), a species known to extend its pseudopodia in an elevated position above the sediment surface (Altenbach et al., 1988). All test surfaces were free of adhering detritus. However, we observed higher proportions of this species at some stations in the Guinea Basin (i.e., Station 16802, off Ivory Coast, 691 $\mathrm{m}$ water depth). All of these specimens were coated by mud cysts (Fig. 1B), similar to those observed in Elphidium incertum (see above) and Elphidium subarcticum (see Poag, 1982). We consider this an indication of an infaunal habitat for this versatile species. 


\section{Discussion}

\section{Elevated microhabitats}

Species which stand errect or attach themselves to elevated substrates are usually suspension feeders that deploy their pseudopodia well above the sediment surface, thereby gaining access to a richer and fresher food supply (DeLaca et al., 1980; Altenbach et al., 1988; Lutze and Altenbach, 1988; Lutze and Thiel, 1989; Mullineaux, 1989; Altenbach et al., 1992, this volume). Recent investigations using Transmission Electron Microscopy revealed that deep-sea foraminifera feed on a variety of particles, mainly at a low trophic level (Heeger, 1990; Gooday et al., 1992a). Recognizable items were mainly pennate diatoms, dinoflagellates, coccoid and thecate algae, bacteria, cuticular remains of copepods and siliceous aggregates. In general, elevated epibenthic species ingested fresher food particles than sediment-dwelling species. These particles originate from lateral advection and it must be taken into account that benthic organisms probably have an impact on deposition rates of particulate matter at the sediment surface. The deposition of particles is influenced by direct and indirect interactions between organisms and particle flux. Suspension feeders exert direct impact on the particle flux by uptake from the bottom water and subsequent deposition of faecal pellets or pseudofaeces, on or in the sediment.

The Norwegian continental margin is characterized by shifting water masses where benthic enrichment by vertically and horizontally transported particles is thought to take place. Together with dense water cascades (Blaume, 1992) and relatively strong bottom currents, this biotope is influenced by intensive lateral advection that favours suspension feeding. The input of primary produced material from the euphotic zone is seasonal, both in terms of quantity and quality of the food par- ticles. However, the sedimentation rates are extremely low, due to the high current velocities. The very thin layer of Holocene sediment probably accumulated as a result of the presence and feeding activity of the suspensionfeeding epifauna (Lutze and Altenbach, 1988). Thus, the life position of the obligate suspension feeder Rupertina stabilis in elevated microhabitats and the use of sponge spicules to support its pseudopodial net, seems to be an optimal adaptation for passive filtering in this environment. This is supported by measurements of the metabolic activity of Rupertina stabilis (Linke, 1992). Unlike specimens of Rhabdammina abyssorum (living in the same biotope), ATP content and the protoplasmic volume of Rupertina stabilis were relatively stable throughout the year, but heat production, oxygen consumption and ATP turnover rates fluctuated during periods of reduced food quality between the main sedimentation events. This coincides with cytological observations of Heeger (1990), who attributed the physiological conditions of the protoplasm of Rupertina stabilis during different times of the year to steady food input. Thus, Rupertina stabilis seems to be optimally adapted in its functional morphology and metabolism to a biotope where during the entire year particles are carried through horizontally, but are not deposited (Linke, 1992). In the uppermost centimeter of sediment, the combined biomass of both species (average value of $560 \mathrm{mg} \mathrm{C}_{\text {org }}$ $\mathrm{m}^{-2}$ ) approaches that of the macrofauna, including epifauna, and measurements of the energy metabolism of Rhabdammina abyssorum point to a more opportunistic survival strategy in an environment that favours suspension feeding (Linke, 1992).

The dominance of the epibenthic Cibicidoides wuellerstorf $i$ in Arctic basins and in the Norwegian-Greenland Sea reflects the scarcity of food particles in the sediment. In contrast to the dominating infaunal species, specimens of Cibicidoides wuellerstorfi were 
sparsely represented in areas with a high flux of organic particles (e.g., below the area of high productivity associated with coastal upwelling off Northwest Africa; Lutze et al., 1986; Altenbach and Sarnthein, 1989). As a suspension feeder occupying elevated positions, Cibicidoides wuellerstorfi does not depend on high vertical flux rates and easily tolerates rates of less than $2 \mathrm{~g} \mathrm{C} \mathrm{m}^{-2} \mathrm{yr}^{-1}$ (Altenbach, 1988). The occurrence of Cibicidoides wuellerstorf $i$ as an epibiont, even on vagrant macrobenthos, is an additional indication of its preference for both an elevated position and bottom water currents. The permanent or temporary attachment of foraminifera to other organisms is well documented by Recent and fossil examples (Lipps, 1983). By colonizing sponges (Bromley and Nordmann, 1971; Kazmierczak, 1973; U. Witte, pers. commun., 1991), brachiopods (Zumwalt and DeLaca, 1980) and vagrant organisms [i.e. pelagic crustaceans (DeLaca and Lipps, 1972) and benthic clams (Haward and Haynes, 1976) ], benthic foraminifera gain access to habitats with an enhanced food supply.

Another form of elevated microhabitat is produced by the foraminifer itself (Altenbach et al., 1992, this volume). Visual observations of the sediment surfaces revealed that Miliolinella subrotunda temporary lives on top of a self-constructed tube. By raising the test far above the sediment surface, the foraminifer is lifted into the area of laminar flow, and larger tubes (up to $6 \mathrm{~mm}$ total height) reach even into the turbulent zone above the sediment surface. Altenbach et al. (1988) emphasized the advantage of elevated suspension feeding, even in areas with very weak currents. They pointed out the critical function of this adaptation: fragile pseudopodia can protrude into the velocity profile of the near-bottom shear flow. This position in the transition layer between the viscous sublayer and turbulent flow (the logarithmic layer), with rapidly increasing velocities and shear stress, offers an increased flux of food particles that may be captured by foraminifera (i.e. Saccorhiza ramosa).

\section{Microhabitats on the sediment surface}

Not dependent on hard substrates Rhabdammina abyssorum colonizes rough sediment surfaces (covered with small stones and biogenic structures) and was occasionally found inhabiting the large burrows of the macrofauna. Both habitats generate turbulent circulation patterns that result either in a local concentration and subsequent deposition, or in enhanced resuspension of particles. The colonization of sediment surfaces by macrofaunal organisms has a strong effect on the physical properties and the microtopography of the sediment (Rhoads and Boyer, 1982). Depressions in the sediment surface (e.g. large burrows of the macro- and megafauna) increase deposition by decreasing flow and shear stress. Small sediment mounds excavated by the burrowing activity of the macrofauna lead to circulation patterns on the lee side of the burrow causing particle enrichment, decreased flow and enhanced deposition. Specimens of $A s$ trorhiza arenaria, a probable suspension feeder, are often located close to sediment mounds excavated by the burrowing crustacean Munida (Tendal and Thomsen, 1988).

Another way for foraminifera to enhance food acquisition is to stand upright in the sediment so that the distal parts from which the pseudopodia arise project well above the sediment-water interface (Cedhagen, 1988). Furthermore, by virtue of their size large foraminifera (e.g. Rhabdammina abyssorum, Hyperammina crassatina) may have an impact on the small-scale hydrodynamics of the bottom currents. A solitary object that penetrates the viscous sublayer increases the shear stress on the surrounding sediment, leading to local enhanced resuspension (Carey, 1983; Nowell and Jumars, 1984; Eckman, 1985). In contrast, currents flow over numerous, densely grouped structures without interacting with single objects ('skimmining flow'). Thus, dense lawns of larger foraminifera with tubular tests may cause deposition of particulate 
matter. Due to their mode of feeding, the epibenthic Hyperammina crassatina may prevent the flux of sedimented organic matter to deeper sediment layers (Meyer-Reil and Köster, 1991). The dense occurrence of large tubular foraminiferal tests undoubtably has an impact on the bottom roughness and could produce 'skimming flow', protecting the sediment from erosion and causing deposition of particles in quiet regions of the tube patch, that can be utilized by the few living foraminifera. In summary, the colonized sediment surface represents a combination of the different effects on bottom water hydrodynamics, where numbers and kinds of structures dictate the combined effect (Vogel, 1981; Ziebis, 1992).

\section{Versatile microhabitat selection}

Recently, it has been suggested (Jorissen, 1988; Corliss and Emerson, 1990; Barmawidjaja et al., 1992) that the microhabitat preference of individual taxa may change as a function of the depth of the Redox Potential Discontinuity (RPD-) Layer and/or the amount of food in the substrate. Sediment surface scavenging foraminifera (e.g. Cribrostomoides subglobosum, Pyrgo rotalaria) can react very rapidly and utilize large amounts of organic matter originating from flux events (Linke, 1989; Heeger, 1990) and play a prominent role in the carbon turnover of the benthic community (Altenbach, 1992; Graf and Linke, 1992). Infaunal species (e.g. Melonis barleeanum) are often very motile and presumably stay at a particular sediment depth when conditions are suitable and attractive. This corroborates the studies of Kitazato (1989), who found specimens of infaunal Uvigerina perched on a polychaete tube. Several authors (Myers, 1943; Richter, 1964; Severin and Erskian, 1981; Severin et al., 1982; among others) have shown that some foraminifera are capable of burrowing in the sediment and migrating back to the sediment surface after burial. Attractive conditions may also be gener- ated by burrowing invertebrates known to accumulate large quantities of food in deeper sediment layers, or biochemical gradients associated with enhanced bacterial production (Graf, 1989; Mackensen and Douglas, 1989; Thomsen, 1991 ). Special adaptions of the sediment community are to be expected in environments characterized by large seasonal fluctuations in oxygen and food supply (Sjoerdsma and Van der Zwaan, 1992).

During oxic periods in the Kiel Bight, dense patches of polychaete tubes colonized by $\mathrm{El}$ phidium excavatum clavatum were observed on the surfaces of sediment cores recovered from a water depth of $28 \mathrm{~m}$. Several studies (Daro and Polk, 1973; Frithsen and Doering, 1986) show that suspension-feeding spionids have a significant impact on bulk sedimentation rates. In a laboratory experiment, dense spionid populations enhanced the sedimentation of microspheres by a factor of approximately 3 . About $25 \%$ of this enhancement was due to the animal activity itself while the rest to the mechanical effect of their tubes (Frithsen and Doering, 1986). Thus, suspension feeding affects bottom water particle dynamics and increases sedimentation of organic detritus. Furthermore, the mechanical trapping effect of Polydora tubes and biodeposition of the polychaete provide an ideal food source for meioand microfauna and bacteria (Alongi, 1985; Schmager, 1988). The faecal pellets produced by these polychaetes are the basis for a rich bacterial community (Alldredge et al., 1987), that are an attractive food source for foraminifera (Schmager, 1988).

The sediments recovered from $28 \mathrm{~m}$ water depth represent an extreme situation. After several days with no additional oxygen supply, the suboxic sediment layer is reduced to a thin film and layers of free sulphide and free oxygen come into direct contact. This situation is obviously utilized and presumably stabilized by chemo-autotroph sulphide-oxydizing bacteria (Jørgensen and Revsbech, 1983). One way for foraminifera to avoid this competition 
for the free oxygen is to occupy elevated substrates above the viscous sublayer, for example on polychaete tubes (Jørgensen and Revsbech, 1985 ). In the present study Elphidium excavatum clavatum and Ammotium cassis were observed on the tubes of Polydora ciliata. Even empty tubes provide an elevated substrate, projecting about $2 \mathrm{~cm}$ above sediment surface and protude through the (stagnant) laminar boundary layer.

In the Baltic, Ammotium cassis and Elphidium incertum colonize the sandier sediments of the basin margins (Lutze, 1974), prefering water of relatively higher salinities $(S>20 \%)$. A vertically moving discontinuity layer was considered to be the determining factor for the distribution of Ammotium cassis (Lutze, 1965 ). Maximum abundances of Ammotium cassis were found where discontinuity layers such as thermo-haloclines (Olsson, 1976; Weinholz, 1985), or internal (in the sediment ) RPD-Layers appear. These discontinuities may favour this species in some manner, although special adaptations are required to withstand such drastic changes in physico-biochemical parameters (Linke et al., in prep.). A passing discontinuity layer with internal waves constitutes an auxiliary energy flow and might imply an additional food supply, due to an increased transport in the bottom water and temporary accumulation, thus redistributing organic particles (Olsson, 1976). Likewise, the RPD-Layer constitutes an accumulation layer in terms of bacterial numbers, as indicated by ATP-biomass maxima at this depth during non-bloom situations (Graf, 1987).

The encystment of Elphidium incertum may possibly be an adaptation to rapid changes in this environment. The agglutinated cysts provide an excellent shelter against mechanical and chemical disturbances (Linke, 1986; Angell, 1990). Enhanced bacterial growth in the interspace between cyst and foraminiferal test, perhaps stimulated by foraminiferal secretions (Langer, 1992), provides the foraminifera an additional food source (gardening or farming effect; Hylleberg, 1975; Gerlach, 1978; Langer and Gehring, 1993). It is also conceivable that the encystment accompanies the onset of reproduction. In the agglutinated Trochammina quadriloba, reproduction starts with the construction of an agglutinated cyst combined with excretion of undigested food from the protoplasm (Salami, 1976), an effect described for numerous foraminifera at the onset of reproduction (Nuglisch, 1985; Angell, 1990). The possibility that benthic foraminifera may migrate upward or downward through the sediment at the end of their life to reproduce (Berger and Wefer, 1988), illustrates some of the complexities that await the paleoceanographer interpreting stable isotope signals.

In spite of their evolutionary success and fossilisation potential, in combination with their abundant and wide-spread occurrence, our knowledge concerning the ecology of benthic foraminifera is still fragmentary. Our collection of observations presented in this study reveals that many foraminifera should be considered as ubiquists in regard to their microhabitats. As the number of our observational data are limited, further observational and experimental data are required (e.g., feeding or simulation experiments as recently demonstrated by Linke, 1989; Heeger, 1990; Altenbach, 1992; Sjoerdsma and Van der Zwaan, 1992). We believe that shifts in behavioural strategies and vertical abundances indicate that the distribution of the foraminiferal fauna can be regarded as a dynamic process. Motile species can be found in elevated microhabitats, on the sediment surface, or within the uppermost sediment layer, in response to changing environmental conditions (e.g. Jorissen et al., 1992). It can be presumed that versatile and ubiquitous species stay at a certain sediment depth only during periods of suitable and attractive conditions, or during certain stages of their life cycle. Thus, the flexible behaviour of benthic foraminifera should be regarded as the expression of a dynamic adaptation to optimize food acquisition, rather than a static con- 
cept emerging from habitat classification (e.g. Corliss and Emerson, 1990; McCorkle et al., 1990; Corliss, 1991).

\section{Conclusions}

Foraminifera adopt a variety of behavioural strategies to obtain their food (Lipps, 1983; Jones and Charnock, 1985). Certain foraminiferal species (e.g. Cibicidoides wuellerstorf $i$ and Rupertina stabilis) can be regarded as strictly epibenthic species, colonizing elevated habitats that are strongly affected by bottom water hydrodynamics. Large epibenthic foraminifera (e.g., Rhabdammina abyssorum, $\mathrm{Hy}$ perammina crassatina) colonize the sediment surface in areas where strong bottom currents occur. They may stand upright in the sediment and project their pseudopodia well above the sediment-water interface, or might have by virtue of their own size an impact on the small scale circulation patterns of the bottom water.

Shifts in behavioural strategies and vertical abundances indicate that the distribution of the foraminiferal faunas is a dynamic process. Motile species changing from epifaunal to infaunal habitats (e.g., Pyrgo rotalaria, Melonis barleeanum, Elphidium excavatum clavatum, Elphidium incertum, Ammotium cassis and Sphaeroidina bulloides) are regarded here as highly adaptable. These species can be found in elevated microhabitats, on the sediment surface, or within the uppermost sediment layer, depending on food availability and/or changing environmental conditions. Thus, many foraminifera should be considered as opportunists in regard to their microhabitats.

\section{Acknowledgements}

We appreciate access to unpublished observations of and fruitful discussions with A.V. Altenbach, T. Heeger, C. Noji, M.B. RomeroWetzel, A. Thies, P. Weinholz, U. Witte and W. Ziebis. Excellent technical assistance was given by $\mathrm{H}$. Beese, B. von Brevern, E. Kamin- ski, W. Queisser, B. Salomon, A. Scheltz and E. Steen. Thanks are also due to the captains and crews of the R.V. Littorina, Meteor, Polarstern and Poseidon for perfect cooperation. Many helpful comments by A.V. Altenbach, M. Langer, A.J. Gooday and A.N. Antia improved the manuscript. This is contribution No. 150 of the Sonderforschungsbereich 313 at Kiel University, funded by the Deutsche Forschungsgemeinschaft.

\section{References}

Alldredge, A.L., Gotschalk, C.C. and MacIntyre, S., 1987. Evidence for sustained residence of macrocrustacean fecal pellets in surface waters off Southern California. Deep-Sea Res., 34: 1641-1652.

Alongi, D.M., 1985. Microbes, meiofauna, and bacterial productivity on tubes constructed by the polychaete Capitella capitata. Mar. Ecol. Prog. Ser., 23: 207-208.

Altenbach, A.V., 1985. Die Biomasse der benthischen Foraminiferen: Auswertung von "Meteor"-Expeditionen im östlichen Nordatlantik. Ph.D. Thesis, Univ. Kiel, 167 pp.

Altenbach, A.V., 1988. Deep-sea benthic foraminifera and flux rates of organic carbon. Rev. Paleobiol. (Vol. Spec.), 2: 719-720.

Altenbach, A.V., 1992. Short term processes and patterns in the foraminiferal response to organic flux rates. In: G.J. van der Zwaan, F.J. Jorissen and W.J. Zachariasse (Editors), Approaches to Palaeoproductivity Reconstructions. Mar. Micropaleontol., 19: 119-129.

Altenbach, A.V., Unsöld, G. and Walger, E., 1988. The hydrodynamic environment of Saccorhiza ramosa (Brady). Meyniana, 40: 119-132.

Altenbach, A.V. and Sarnthein, M., 1989. Productivity record in benthic foraminifera. In: W.H. Berger, V.S. Smetacek and G. Wefer (Editors), Productivity of the Ocean: Present and Past. Wiley, New York, pp. 255269.

Altenbach, A.V., Heeger, T., Linke, P., Spindler, M. and Thies, A., 1992. Milionella subrotunda (Montagu), a miliolid foraminifer building large detritic tubes for a temporary epibenthic lifestyle. In: M.R. Langer (Editor), Foraminiferal Microhabitats. Mar. Micropaleontol., 20: 293-301.

Angell, R.W., 1990. Observations on reproduction and juvenile test building in the foraminifer Trochammina inflata. J. Foraminiferal Res., 20: 246-247.

Barmawidjaja, D.M., Jorissen, F.J., Puskaric, S. and Van der Zwaan, G.J., 1992. Microhabitat selection by benthic foraminifera in the northern Adriatic Sea. J. Foraminiferal Res., 22: 297-317. 
Barnett, P.R.O., Watson, J. and Conelly, D., 1984. A multiple corer for taking virtually undisturbed samples from shelf bathyal and abyssal sediments. Oceanol. Acta, 7: 399-408.

Berger, W.H. and Wefer, G., 1988. Benthic deep-sea foraminifera: possible consequences of infaunal habitat for paleoceanographic interpretation. J. Foraminiferal Res., 18: 147-150.

Bernhard, J.M., 1986. Characteristic assemblages and morphologies of benthic foraminifera from anoxic, organic-rich deposits: Jurassic through Holocene. J. Foraminiferal Res., 16: 207-215.

Blaume, F., 1992. Hochakkumulationsgebiete am norwegischen Kontinentalhang: Sedimentologische Abbilder Topographie-geführter Strömungsmuster. Ber. Sonderforschungsbereich 313, Univ. Kiel, 36, 150 pp.

Bourke, R.H., Newton, J.L., Paquette, R.G. and Tunnicliff, M.D., 1987. Circulation and watermasses of the East Greenland shelf. J. Geophys. Res., 92(C7): 67296740.

Bromley, R.G. and Nordmann, E., 1971. Maastrichtian adherent foraminifera encircling clionid pores. Bull. Geol. Soc. Den., 20: 96-104.

Carey, D.A., 1983. Particle resuspension in the benthic boundary layer induced by flow around polychaete tubes. Can. J. Fish. Aquat. Sci., 40: 301-308.

Cedhagen, T., 1988. Position in the sediment and feeding of Astrorhiza limicola Sandahl, 1857 (Foraminiferida). Sarsia, 73: 43-47.

Corliss, B.C., 1985. Microhabitats of benthic foraminifera within deep-sea sediments. Nature, 314: 435-438.

Corliss, B.C., 1991. Morphology and habitat preferences of benthic foraminifera from the northwest Atlantic Ocean. Mar. Micropaleontol., 17: 195-236.

Corliss, B.C and Chen, C., 1988. Morphotype patterns of Norwegian Sea deep-sea benthic foraminifera and ecological implications. Geology, 16: 716-719.

Corliss, B.C. and Emerson, S., 1990. Distribution of Rose Bengal stained deep-sea benthic foraminifera from the Nova Scotian continental margin and Gulf of Maine. Deep-Sea Res., 37: 381-400.

Corliss, B.C. and Fois, E., 1990. Morphotype analysis of deep-sea benthic foraminifera from the northwest Gulf of Mexico. Palaios, 5: 589-605.

Daro, M.H. and Polk, P., 1973. The autecology of Polydora ciliata along the Belgian coast. J. Exp. Mar. Biol. Ecol., 54: 21-38.

DeLaca, T.E. and Lipps, J.H., 1972. The mechanism and adaptive significance of attachment and substrate pitting in the foraminiferan Rosalina globularis (d'Orbigny). J. Foraminiferal Res., 2: 68-72.

DeLaca,T.E., Lipps, J.H. and Hessler, R.R., 1980. The morphology and ecology of a new large Antarctic foraminifer (Textulariina: Notodendrodidae nov.). J. Linn. Soc. London Zool., 69: 205-224.

Eckmann, J.E., 1985. Flow disruption by an animal tube mimic affects sediment bacterial colonization. J. Mar. Res., 43: 419-435.

Frithsen, J.B. and Doering, P.H., 1986. Active enhancement of particle removal from the water column by tentaculate benthic polychaetes. Ophelia, 25: 169-182.

Gammelsröd, T. and Rudels, B., 1983. Hydrographic and current measurements in the Fram Strait, August 1981. Polar Res., 1: 115-126.

Gerlach, S.A., 1978. Food-chain relationships in subtidal silty sand marine sediments and the role of meiofauna in stimulating bacterial productivity. Oecologia, 33: 55-69.

Gooday, A.J., 1986. Meiofaunal foraminiferans from the bathyal Porcupine Seabight: size structure, taxonomic composition, species diversity and vertical distribution in the sediment. Deep-Sea Res., 33: 1345-1 373.

Gooday, A.J., 1990. Recent deep-sea agglutinated foraminifera: a brief review. In: C. Hemleben, M.A. Kaminski, W. Kuhnt and D.B. Scott (Editors), Paleoecology, Biostratigraphy, Paleoceanography and Taxonomy of Agglutinated Foraminifera. (NATO ASI Ser., C327.) Kluwer, Dordrecht, pp. 271-304.

Gooday, A.J., Levin, L.A., Linke, P. and Heeger, T., 1992a. The role of benthic foraminifera in deep-sea food webs and carbon cycling. In: G.T. Rowe and V. Pariente (Editors), Deep-Sea Food Chains and the Global Carbon Cycle. (NATO ASI Ser., C360.) Kluwer, Dordrecht, pp. 63-91.

Gooday, A.J., Levin, L.A., Thomas, C.L. and Hecker, B., 1992b. The distribution and ecology of Bathysiphon filiformis Sars and B. major d.e. Solin (Protista, Foraminiferida) on the continental slope off North Carolina. J. Foraminiferal Res., 22: 129-146.

Graf, G., 1987. Winter inversion of biomass and activity profile in a marine sediment. Mar. Ecol. Prog. Ser., 33: 231-235.

Graf, G., 1989. Benthic-pelagic coupling in a deep-sea benthic community. Nature, 341: 437-439.

Graf, G. and Linke, P., 1992. Adensine nucleotides as indicators of deep-sea benthic metabolism. In: G.T. Rowe and V. Pariente (Editors), Deep-Sea Food Chains and the Global Carbon Cycle. (NATO ASI Ser., C360.) Kluwer, Dordrecht, pp. 237-243.

Haward, N.J.B. and Haynes, J.R., 1976. Chlamys opercularis (Linnaeus) as a mobile substrate for foraminifera. J. Foraminiferal Res., 6: 30-38.

Heeger, T., 1990. Elektronenmikroskopische Untersuchungen zur Ernährungsbiologie benthischer Foraminiferen. Ber. Sonderforschungsbereich 313, Univ. Kiel, 21, 139 pp.

Hempel, C., 1957. Über den Röhrenbau und die Nahrungsaufnahme einiger Spioniden (Polychaeta sedentaria). Helgol. Wiss. Meeresunters., 7: 80-92.

Hylleberg, J., 1975. Selective feeding by Abarenicola pacifica with notes on Abarenicola vagabunda and a concept of gardening in lugworms. Ophelia, 14: 113-137. 
Jones, R.W. and Charnock, M.A., 1985. "Morphogroups" of agglutinating Foraminifera. Their life positions and feeding habitats and potential applicability in (paleo)ecological studies. Rev. Paleobiol., 4: 311 320.

Jørgensen, B.B. and Revsbech, N.P., 1983. Colorless sulfur bacteria, Beggiatoa sp. and Thiovulum sp. in $\mathrm{O}_{2}$ and $\mathrm{H}_{2} \mathrm{~S}$ microgradients. Appl. Environ. Microbiol., 45: 1261-1270.

Jørgensen, B.B. and Revsbech, N.P., 1985. Diffusive boundary layers and the oxygen uptake of sediments and detritus. Limnol. Oceanogr., 30: 111-122.

Jorissen, F.J., 1987. The distribution of benthic foraminifera in the Adriatic Sea. Mar. Micropaleontol., 12: 21-48.

Jorissen, F.J., 1988. Benthic Foraminifera from the Adriatic Sea: Principles of Phenotypic Variation. Utrecht Micropaleontol. Bull., 37, 176 pp.

Jorissen, F.J., Barmawidjaja, D.M., Puskaric, S. and Van der Zwaan, G.J., 1992. Vertical distribution of benthic foraminifera in the northern Adriatic Sea: The relation with the organic flux. In: G.J. van der Zwaan, F.J. Jorissen and W.J. Zachariasse (Editors), Approaches to Palaeoproductivity Reconstructions. Mar. Micropaleontol., 19: 131-146.

Kazmierczak, J., 1973. Tolypammina vagans (Foraminiferida ) as inhabitant of the Oxfordian siliceous sponge. Acta Palaeontol. Pol., 18: 95-115.

Kitazato, H., 1989. Vertical distribution of benthic foraminifera within sediments. Bull. Jpn. Assoc. Benth., 35/36: 41-51.

Köster, M., Jensen, P. and Meyer-Reil, L.-A., 1991. Hydrolytic activity asssociated with organisms and biogenic structures in deep-sea sediments from the Norwegian-Greenland Sea. In: R.J. Christ (Editor), Microbial Enzymes in Aquatic Environments. Springer, Berlin, pp. 298-310.

Langer, M.R., 1992. Biosynthesis of glycosaminoglycans in foraminifera: A review. Mar. Micropaleontol., 19: 245-255.

Langer, M.R. and Gehring, C., 1993. Bacteria farming: A possible feeding strategy of some smaller motile foraminifera. J. Foraminiferal Res., in press.

Lee, J.J., 1990. Brief perspective on the autecology of marine protozoa. In: P.C. Reid, C.M. Turley and P.H. Burkill (Editors), Protozoa and their Role in Marine Processes. (NATO ASI Ser., G25.) Springer, Berlin, pp. 181-194.

Linke, P., 1986. Biomasse und Stoffwechsel-Leistungen benthischer Foraminiferen. Ms. Thesis, Univ. Kiel, 110 pp.

Linke, P., 1989. Lebendbeobachtungen und Untersuchungen des Energiestoffwechsels benthischer Foraminiferen aus dem Europäischen Nordmeer. Ber. Sonderforschungsbereich 313, Univ. Kiel, 18, 123 pp.

Linke, P., 1992. Metabolic adaptations of deep-sea benthic foraminifera to seasonally varying food input. Mar. Ecol. Prog. Ser., 81: 51-63.

Linke, P., Weinholz, P. and Heeger, T., in prep. Distribution and ecology of the foraminiferan Ammotium cassis (Parker) in Kiel Bight, Baltic Sea.

Lipps, J.H., 1983. Biotic interactions in benthic Foraminifera. In: M.J.S. Tevesz and P.L. McCall (Editors), Biotic Interactions in Recent and Fossil Benthic Communities. Plenum, New York, pp. 331-376.

Lutze, G.F., 1965. Zur Foraminiferen-Fauna der Ostsee. Meyniana, 15: 75-142.

Lutze, G.F., 1974. Foraminiferen der Kieler Bucht (westliche Ostsee ): 1. "Hausgartengebiet" des Sonderforschungsbereiches 95, Univ. Kiel. Meyniana, 26: 9-22.

Lutze, G.F., 1987. Benthische Foraminiferen: Vertikale Verteilung in den obersten Sedimentlagen und Probleme bei der Entnahme von Standard-Proben. Ber. Sonderforschungsbereich 313 , Kiel Univ., 6, pp. 7987.

Lutze, G.F., Pflaumann, U. and Weinholz, P., 1986. Jungquartäre Fluktuationen der benthischen Foraminiferenfaunen in Tiefsee-Sedimenten vor NW-Afrika. Eine Reaktion auf Produktivitätsänderungen im $\mathrm{Ob}$ erflächenwasser. Meteor Forschungsergebn., Reihe C, 40: $163-180$.

Lutze, G.F. and Salomon, B., 1987. Foraminiferen-Verbreitung zwischen Norwegen und Grönland: ein WestOst Profil. Ber. Sonderforschungsbereich 313, Univ. Kiel, 6: 69-78.

Lutze, G.F. and Altenbach, A.V., 1988. Rupertina stabilis (Wallich), a highly adapted, suspension feeding foraminifer. Meyniana, 40: 55-69.

Lutze, G.F. and Thiel, H., 1989. Epibenthic foraminifera from elevated microhabitats: Cibicidoides wuellerstorfi and Planulina ariminensis. J. Foraminiferal Res., 19: 153-158.

Mackensen, A. and Douglas, R.G., 1989. Down-core distribution of live and dead deep-water benthic foraminifera in box cores from the Wedell Sea and the California continental borderland. Deep-Sea Res., 36: 879900.

McCorkle, D.C., Keigwin, L.D., Corliss, B.H. and Emerson, S.R., 1990. The influence of microhabitats on the carbon isotopic composition of deep-sea benthic foraminifera. Paleoceanography, 5: 161-185.

Meyer-Reil, L.-A. and Köster, M., 1991. Fine-scale distribution of hydrolytic activity associated with foraminiferans and bacteria in deep-sea sediments of the Norwegian-Greenland Sea. Kiel. Meeresforsch., Sonderh., 8: 121-126.

Miller, K.G. and Lohmann, G.P., 1982. Environmental distribution of recent benthic foraminifera on the northeast United States continental slope. Geol. Soc. Am. Bull., 93: 200-206.

Mullineaux, L.S., 1987. Organisms living on manganese nodules: Implications for settlement and feeding. Limnol. Oceanogr., 34: 165-184. 
Mullineaux, L.S., 1988a. Taxonomic notes on large agglutinated foraminifers encrusting manganese nodules, including the description of a new genus Chondrodapis (Komokiacea ). J. Foraminiferal Res., 18: 46-53.

Mullineaux, L.S., 1988b. The role of settlement in structuring a hard-substratum community in the deep-sea. J. Exp. Mar. Biol. Ecol., 120: 247-261.

Mullineaux, L.S., 1989. Vertical distribution of the epifauna on manganese nodules: Implications for settlement and feeding. Limnol. Oceanogr., 34: 1247-1262.

Myers, E.H., 1943. Life activities of foraminifera in relation to marine ecology. Proc. Am. Philos. Soc., 86: 439458.

Nowell, A.R.M. and Jumars, P.A., 1984. Flow environments of aquatic benthos. Ann. Rev. Ecol. Syst., 15: 303-328.

Nuglisch, K., 1985. Foraminiferen. Neue Brehm-Bücherei, Ziemsen Verlag, Wittenberg, $174 \mathrm{pp}$.

Poag, C.W., 1982. Environmental implications of test-tosubstrate attachment among some modern sublittoral foraminifera. Bull. Geol. Soc. Am., 93: 252-268.

Olsson, I., 1976. Distribution and ecology of the foraminiferan Ammotium cassis (Parker) in some Swedish estuaries. Zoon, 4: 137-147.

Rhoads, D.C. and Boyer, L.F., 1982. The effects of marine benthos on physical properties of sediments. A successional perspective. In: M.J.S. Tevesz and P.L. McCall (Editors), Biotic Interactions in Recent and Fossil Benthic Communities. Plenum, New York, pp. 3-43.

Richter, G., 1964. Zur Ökologie der Foraminiferen. III. Verdriftung und Transport in der Gezeitenzone. Nat. Mus., 95: 51-62.

Richter, G., 1965. Zur Ökologie der Foraminiferen. II. Lebensraum und Lebensweise von Nonion depressulum, Elphidium excavatum und Elphidium selseyense. Nat. Mus., 94: 421-430.

Salami, M.B., 1976. Biology of Trochammina cf. T. quadriloba (Höglund), an agglutinating foraminifer. J. Foraminiferal Res., 6: 142-153.

Schmager, C., 1988. Einfluß rasenbildender Spioniden auf den Stoffaustausch am Meeresboden. Ms. Thesis, Univ. Kiel, 64 pp.

Severin, K.P. and Erskian, M.G., 1981. Laboratory experiments on the vertical movement of Quinqueloculina impressa (Reuss) through sand. J. Foraminiferal Res., 11:133-136.

Severin, K.P., Culver, S.J. and Blanpied, C., 1982. Burrows and trails produced by Quinqueloculina impressa (Reuss), a benthic foraminifer, in fine grained sediment. Sedimentology, 29: 897-901.

Sheehan, R. and Banner, F.T., 1972. The pseudopodia of Elphidium incertum. Rev. Esp. Micropaleontol., 4: 3163.
Sjoerdsma, P.G. and Van der Zwaan, G.J., 1992. Simulating the effect of changing organic flux and oxygen content on the distribution of benthic foraminifera. In: G.J van der Zwaan, F.J. Jorissen and W.J. Zachariasse (Editors), Approaches to Palaeoproductivity Reconstructions. Mar. Micropaleontol, 19: 163-180.

Tendal, O.S. and Thomsen, E., 1988. Observations on the life position and size of the large foraminifer Astror hiza arenaria Norman, 1876 from the shelf off northern Norway. Sarsia, 73: 39-42.

Thies, A., 1990. The ecology, distribution and taxonomy of Crithionina hispida Flint, 1889. In: C. Hemleben, M.A. Kaminiski, W. Kuhnt and D.B. Scott (Editors), Paleoecology, Biostratigraphy, Paleoceanography and Taxonomy of Agglutinated Foraminifera. (NATO ASI Ser., C327. ), Kluwer, Dordrecht, pp. 305-313.

Thies, A., 1991. Die Benthosforaminiferen im Europäischen Nordmeer. Ber. Sonderforschungsbereich 313, Univ. Kiel, 31, 97 pp.

Thomsen, L., 1991. Treatment and splitting of samples for bacteria and meiofauna biomass determinations by means of a semi-automatic image analysis system. Mar. Ecol. Prog. Ser., 71: 301-306.

Van der Zwaan, G.J. and Jorissen, F.J., 1991. Biofacial patterns in river-induced shelf anoxia. In: R.V. Tyson and T.H. Pearson (Editors), Modern and Ancient Continental Shelf Anoxia. Geol. Soc. Spec. Publ., 58: 65-82.

Van Dover, C.L., Berg, C.J. and Turner, R.D., 1988. Recruitment of marine invertebrates to hard substrates at deep-sea hydrothermal vents on the East Pacific Rise and Galapagos spreading centre. Deep-Sea Res., 35: 1833-1849.

Vogel, S., 1981. Life in Moving Fluids. The Physical Biology of Flow. Willard Grant Press, Boston, $352 \mathrm{pp}$.

Wefer, G., 1976a. Umwelt, Produktion und Sedimentation benthischer Foraminiferen in der Westlichen Ostsee. Rep. Sonderforschungsbereich 95, Univ. Kiel, 14, $103 \mathrm{pp}$.

Wefer, G., 1976b. Environmental effects on growth rates of benthic foraminifera (shallow water, Baltic Sea). Marit. Sediments, Spec. Publ., 1: 39-50.

Weinholz, P., 1985. Auswertungen mikropaläontologischer Datensätze aus der Kieler Bucht. Ms. Thesis, Univ. Kiel, 99 pp.

Ziebis, W., 1992. Experimente im Strömungskanal zum EinfluB der Makrofauna auf den bodennahen Partikeltransport. Ber. Sonderforschungsbereich, Univ. Kiel, $37,83 \mathrm{pp}$.

Zumwalt, G.S. and DeLaca, T.E., 1980. Utilization of brachipod feeding currents by epizoic foraminifera. $\mathbf{J}$. Paleontol., 54: 477-484. 